\title{
Evaluating the Role of Education as a Birth Control Policy in Burkina Faso: A Propensity Score Weighting Approach
}

\author{
David Aimé Zoundi ${ }^{1}$, Jean-Louis Bago ${ }^{1}$, Wamadini dite Minata Souratié ${ }^{2} \&$ Miaba Louise Lompo $^{3}$ \\ ${ }^{1}$ Department of Economics, Laval University, Canada \\ ${ }^{2}$ Unit of Training and Research in Economics and Management, University of Ouaga II, Burkina Faso \\ ${ }^{3}$ Department of Information and Communication, Laval University, Canada \\ Correspondence: Jean-Louis Bago, Department of Economics, Laval University, Canada. E-mail: \\ jean-louis.bago.1@ulaval.ca
}

Received: June 29, 2018

doi:10.5539/ies.v11n9p36
Accepted: July 30, $2018 \quad$ Online Published: August 28, 2018

URL: https://doi.org/10.5539/ies.v11n9p36

\begin{abstract}
We use the 2014 round of Burkina Faso's Demographic and Health Surveys (DHS) to identify and quantify the causal effect of women's education on their fertility outcomes focusing on two fertility indicators: the total number of children ever born and the age at first birth. However, women's educational attainments may reflect the difference in term of access to schooling or individual characteristics such the family wealth, causing a threat to the empirical identification. In order to achieve consistent estimation, our empirical strategy follows Imbens (2000) and uses the propensity score weighting (PSW) approach to generate an appropriate counterfactual group accounting for education levels. Results from the PSW estimation suggest that education reduces the number of children per woman and delays women's first birth in Burkina Faso. Hence, promoting girls education is an efficient policy to achieve birth control in Burkina Faso.
\end{abstract}

Keywords: education, birth control, fertility, propensity score weighting, Burkina Faso

\section{Introduction}

Education plays a key role in women empowerment decisions such as employment participation (Aslam, 2013; Bhat, 2015), contraception use (Bbaale \& Mpuga, 2011), family planning behaviour (Khan, Mishra, Arnold, \& Abderrahim, 2007), and fertility preference (Cohen, Kravdal, \& Keilman, 2011; Pradhan \& Canning, 2013; Rodríguez-Vignoli \& Cavenaghi, 2014; Testa, 2014). The effect of education on human societies' demographic behaviour has been of great interest to population science researchers (Bbaale \& Mpuga, 2011; Bongaarts \& Casterline, 2013). In developed countries, a large body of studies suggest that education tends to reduce women's fertility. Becker (1960) finds out that education increases the economic cost of birth and has a negative effect on fertility. (Grossman, 1972) also claims that education improves on women's knowledge and ability to process information about fertility options. In a study carried out in the United States (Currie \& Moretti, 2003) suggests that educated women therefore tend to have fewer children. In fact, their results show that females with a college degree have on average $20 \%$ fewer children than those who have a high school degree. The literature also supports the claim that education delays women's first birth (Chicoine, 2012; Ferré, 2009). A recent paper by Lompo, Bago, and Souratié (2018) shows that education increases adolescents' contraception use in Burkina Faso and Nigeria. Together, these results support the hypothesis that education reduces fertility through the increase of contraception use (Larsson \& Stanfors, 2014).

Yet, in developing countries such as Burkina Faso, despite the implementation of several education policies for girls and women, the level of fertility is still one of the highest in the world (Bongaarts \& Casterline, 2013; Casterline \& El-Zeini, 2014) and teenage motherhood remains largely spread. A worthy feature is the great increase observed in the girls' enrollment rate in primary school in Burkina Faso from 38.2\% in 2000 to $64.4 \%$ in 2014 (MENA, 2014) (Note 1) while the rate of fertility still points at 5.4 children per women on average (UN, 2016). This stylized fact raised the following question: does women's education significantly influence women's fertility in Burkina Faso? The answer to this question is increasingly important considering the fact that population growth in developing countries slows down the GDP per capita (Bongaarts, 2016; Garenne \& Ferdi, 2016). Empirical studies agree on an inverse relationship between education and fertility (Doliger, 2004). 
However, the empirical attempts to quantify the effect of education on fertility lead to mixed results since education is potentially endogenous (Zanin, Radice, \& Marra, 2015). In order to control the endogeneity of education, Zanin et al. (2015) uses instrumental variables to estimate the effect of education in Malawi. Their results suggest an inverted-U shape relationship between education and fertility among women who are more than 30 years old and live in rural areas of Malawi. Moreover, in a quasi-experimental study, Black, Devereux, and Salvanes (2008) and Leon (2004) find a significant causal effect of education on women's fertility. Another study conducted by Bbaale and Mpuga (2011) also suggests a non-linear relationship between women's education and their fertility decisions. For instance, their results suggest that female education, especially in the secondary and post-secondary levels, increases the likelihood of using contraceptives and reduces fertility in Uganda. A primary school education of women in Uganda has a weak influence on fertility. On the other hand, having a secondary school education significantly reduces women's number of children. In addition, women who do not attend school enter union on average 4 years earlier than women with secondary schooling and hence have their first child earlier.

In order to account for education endogeneity, we use a propensity score weighting (PSW) approach to provide an empirical contribution to the analysis of the causal relationship of education on fertility in developing countries. Using data from Burkina Faso's 2014 Demographic and Health Survey (DHS), we analyze the impact of education on two fertility indicators namely the number of children ever born and the age at first birth. Our results suggest that education reduces the number of children ever born from a woman and delays women's first birth. Our results are consistent with Bbaale and Mpuga (2011) who find out that education helps to increase women's preference for family planning in Uganda.

The rest of the paper is organized as follows. Section 2 presents the data and the empirical method. Section 3 exposes the descriptive statistics. Section 4 presents the results and Section 5 provides a discussion and a conclusion to the paper.

\section{Data and Identification Strategy}

\subsection{Data}

We use data from Burkina Faso's 2014 Demographic and Health Survey (DHS) to estimate the effect of women's education on fertility decisions. We focus on two fertility decisions: the number of children and the age at first birth. This database contains information on the socio-economic characteristics of participants such as education, number of children, age at first marriage, age at first birth, religion and geographical location (area of residence, regions of residence). All the variables are from women's questionnaire. We excluded from our sample women with missing information on fertility and women who have never got a child. Our final sample contains 17,087 women between the ages of 15 and 49 who have given birth at least once.

\subsection{Identification Strategy}

Our identification strategy consists of a combination of PSW and a Poisson regression in order to assess the effect

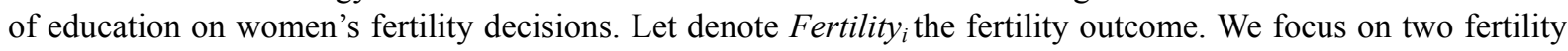
decisions: the total number of children ever born and the age at first birth. As the dependent variables are count data we use the Poisson model. The conditional mean of the model $\lambda_{i}$ is:

$$
\lambda_{i}=\exp \left(\alpha_{0}+\sum_{j=1}^{2} \alpha_{j 1} \text { Education }_{j i}+X_{i}^{\prime} \gamma+\varepsilon\right)
$$

Where $\mathrm{X}$ includes all the other variables, that affect a woman's fertility decision.

However, since education is not a random treatment and women with a given level of education may share common characteristics; standard estimates are subjected to selection bias (Rosenbaum, 1987). We follow Imbens (2000) and use the propensity score with multi-value treatments to balance characteristics, the treatment and control groups and correct the sample selection. We use a two-step empirical methodology.

In the first step, we focus on the determinant of education in order to estimate the probability of a woman to receive a given level of education. We define Education $_{i}$ the level of education as a categorical variable equal to 1 if a female reported she has no education, 2 if she has a primary education level, 3 if she has a secondary or a higher education level.

Following Rosenbaum (1987) and Imbens (2000), we first use an ordered probit to estimate the probability for a female to have primary or secondary education and then we estimate the propensity score of "treatment".

The model is presented as follows: 


$$
\text { Education }_{i}=\left\{\begin{array}{ccr}
1 & \text { if } & \text { Education }_{i}^{*} \leq 0 \\
2 & \text { if } & 0<\text { Education }_{i}^{*} \leq \mu \\
3 & \text { if } & \text { Education }_{i}^{*}>\mu
\end{array}\right.
$$

where Education $_{i}^{*}=X_{i}^{\prime} \beta+\varepsilon$ is a latent variable whose value determines a woman's level of education. $X_{i}$ is a vector of all the factors that influence the level of education, including the age variable, the dummy variables of the wealth index, and the dummies of the ethnic groups and the area of residence.

After estimating these weighting score, we built an appropriate set of counterfactual women. This procedure consists in selecting girls who have no education but have the same characteristics as girls with primary education and secondary education.

In the second step, these weights are used in our Poisson regressions to estimate the effect of each level of education on the fertility indicators.

\section{Descriptive Statistics}

Table 1 presents the descriptive statistics of women socio-economic characteristics. The results show that the number of children ranges between 0 and 17 children with an average of 3.28 children per woman. On average, women have their first child at the age of 19 in Burkina Faso. In our sample, the average age of women is 29 years old. A large percentage of these women are married or living with a partner $(78.38 \%)$. With regard to education, the statistics indicate that $73 \%$ of women never went to school, $14.09 \%$ have a primary education level and only $12.2 \%$ have a secondary education level or higher. This low literacy rate in our sample reflects the adult literacy rate for the country, estimated at $15.45 \%$ (World Bank, 2012). The same figure appears for their husband. In fact, we find that more than $78 \%$ of men have no education, while only $8.16 \%$ have attained higher education. Another fertility issue for women in Burkina Faso is the practice of child marriage that reduces women's empowerment and increases the likelihood of early childbearing. In our sample, $46.31 \%$ of women are married before the age of 18 . The results also show that Mossi ethnic group is the largest part representing 52.3\% of our sample. The majority of women $(68.5 \%)$ live in rural area.

Table 1. Descriptive statistics

\begin{tabular}{lcccc}
\hline Variables & Mean & Std. Err & Min. & Max. \\
\hline Women Fertility & & & & \\
Number of children & 3.288 & 2.856 & 0 & 17 \\
Age at first birth & 19.059 & 3.103 & 12 & 38 \\
Female Education & & & & \\
No Education & 0.730 & 0.244 & 0 & 1 \\
Primary & 0.140 & 0.347 & 0 & 1 \\
Secondary or more & 0.128 & 0.335 & 0 & 1 \\
Married & 0.783 & 0.411 & 0 & 1 \\
Victim of Child Mariage & 0.463 & 0.498 & 0 & 1 \\
Age & 28.838 & 9.462 & 15 & 49 \\
Employed & 0.768 & 0.422 & 0 & 1 \\
Partner's Education & & & & \\
No Education & 0.784 & 0.296 & 0 & 1 \\
Primary & 0.123 & 0.329 & 0 & 1 \\
Secondary or more & 0.091 & 0.291 & 0 & 1 \\
Wealth Index & & & & \\
Poorest & 0.165 & 0.296 & 0 & 1 \\
Poorer & 0.180 & 0.384 & 0 & 1 \\
Middle & 0.191 & 0.393 & 0 & 1 \\
Richer & 0.210 & 0.407 & 0 & 1 \\
Richest & 0.251 & 0.433 & 0 & 1 \\
\hline & & & &
\end{tabular}




\begin{tabular}{lllll}
\hline Ethnicity & & & & \\
Mossi & 0.523 & 0.217 & 0 & 1 \\
Peulh & 0.079 & 0.269 & 0 & 1 \\
Gourmatche & 0.061 & 0.239 & 0 & 1 \\
Others & 0.335 & 0.472 & 0 & 1 \\
Religion & & & & \\
Muslim & 0.599 & 0.374 & 0 & 1 \\
Christians & 0.307 & 0.461 & 0 & 1 \\
Others & 0.093 & 0.291 & 0 & 1 \\
Residence & & & & \\
Urban & 0.310 & 0.313 & 0 & 1 \\
Rural & 0.685 & 0.464 & 0 & 1 \\
\hline
\end{tabular}

\section{Empirical Results}

\subsection{Education and Women Socio-Economic Characteristics}

This section analyzes the relationships between women's level of education and their socio-economic characteristics. Table 2 presents the socio-economic characteristics of women by the level of education before weighting the sample. With regards to group of females for each education level, these statistics indicate a huge difference in terms of characteristics. In terms of wealth, we observe that around $41 \%$ of women with no education come from poor and very poor families while only $8 \%$ of women with secondary school education come from poor or very poor families. This represents a huge difference of 33 percent. In contrast, $74.3 \%$ of women with a secondary or higher education come from the richest families while only $13 \%$ of women with no education come from the richest family representing a difference of 61 percent. This result reveals a large difference in terms of wealth among women with a high level of education and women with a low level of education. A woman's access to education is positively associated with her family's wealth index. We also observe that $87 \%$ of women with no education are married while only $64 \%$ and $44 \%$ of those with primary education and secondary or higher education respectively are married. Moreover, we also find evidence of positive associative matching. In fact, women's education is positively correlated with their partners' education. Indeed, $87.8 \%$ of women with no education also have a partner with no education. In addition, the results show a large difference in terms of residence area. In fact, $81 \%$ of women with no education live in rural area while only $22.2 \%$ of women with secondary or higher education actually live in rural area. The same figure is observed in Figure 1 which represents the distribution of individual characteristics by level of education using boxplots. These graphs confirm a large difference as far as the characteristics between women with no education, those with primary school education and those with a secondary and higher education are concerned. To account for these differences, we calculated the propensity scores which represent the probability of each woman to have a given level of education.

Table 2. Descriptive statistics by the level of education

\begin{tabular}{lccc}
\hline \multicolumn{3}{c}{ Variables average by level of education } \\
\hline Variables & No Education & Primary & Secondary and more \\
Fertility decisions & & & \\
Age at first birth & 18.858 & 19.214 & 21.177 \\
Number of children & 3.936 & 2.091 & 0.927 \\
Wealth Index & & & \\
Poorest & 0.208 & 0.0752 & 0.0218 \\
Poorer & 0.219 & 0.107 & 0.0431 \\
Middle & 0.224 & 0.148 & 0.0562 \\
Richer & 0.217 & 0.242 & 0.136 \\
Richest & 0.130 & 0.428 & 0.743 \\
Marital status & & & \\
\hline
\end{tabular}




\begin{tabular}{|c|c|c|c|}
\hline Single & 0.126 & 0.351 & 0.581 \\
\hline Married & 0.874 & 0.649 & 0.419 \\
\hline Child Marriage & 0.547 & 0.340 & 0.123 \\
\hline No Child Marriage & 0.453 & 0.660 & 0.877 \\
\hline \multicolumn{4}{|c|}{ Husband Education } \\
\hline No Education & 0.878 & 0.501 & 0.187 \\
\hline Primary & 0.0953 & 0.305 & 0.149 \\
\hline Secondary or more & 0.0266 & 0.194 & 0.664 \\
\hline \multicolumn{4}{|l|}{ Age group } \\
\hline $15-19$ & 0.143 & 0.303 & 0.379 \\
\hline $20-24$ & 0.171 & 0.224 & 0.258 \\
\hline $25-29$ & 0.175 & 0.184 & 0.143 \\
\hline $30-34$ & 0.164 & 0.122 & 0.111 \\
\hline $35-39$ & 0.134 & 0.0756 & 0.0567 \\
\hline $40-44$ & 0.117 & 0.0499 & 0.0349 \\
\hline $45-49$ & 0.0950 & 0.0424 & 0.0177 \\
\hline \multicolumn{4}{|l|}{ Ethnicity } \\
\hline Mossi & 0.524 & 0.503 & 0.545 \\
\hline Peulh & 0.0973 & 0.0316 & 0.0286 \\
\hline Gourmatche & 0.0686 & 0.0403 & 0.0435 \\
\hline Others & 0.311 & 0.425 & 0.383 \\
\hline \multicolumn{4}{|l|}{ Residence area } \\
\hline Urban & 0.190 & 0.533 & 0.778 \\
\hline Rural & 0.810 & 0.467 & 0.222 \\
\hline \multicolumn{4}{|l|}{ Religion } \\
\hline Muslims & 0.637 & 0.520 & 0.471 \\
\hline Christians & 0.245 & 0.436 & 0.518 \\
\hline Others & 0.118 & 0.0445 & 0.0104 \\
\hline
\end{tabular}

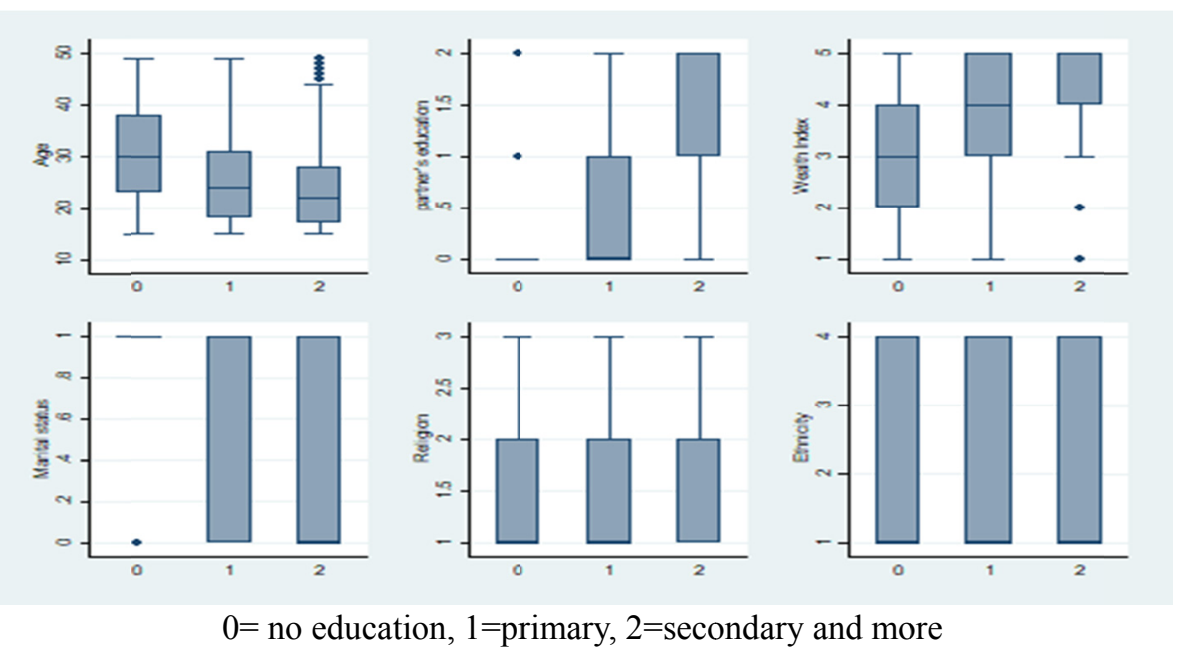

Figure 1. Boxplot by the level of education before weighting

\subsection{Predicting the Propensity Score}

We use an ordered probit to estimate Equation (2) and calculate the propensity scores. The results of scores' 
estimation are reported in Table 3 (Column 1, 2 and 3). These scores represent the probability of each woman have a given education level with respect to her individual characteristics. Caliendo and Kopeinig (2008) showed that these scores are used to weight the sample and eliminate the differences. After weighting our sample, Figure 2 suggests that the three groups are similar.

Table 3. Ordered probit regressions to generate the p-scores

\begin{tabular}{|c|c|c|c|c|}
\hline VARIABLES & coef & $\begin{array}{c}\text { No Education } \\
(1) \\
\end{array}$ & $\begin{array}{c}\text { Primary } \\
(2)\end{array}$ & $\begin{array}{l}\text { Secondary or more } \\
\text { (3) }\end{array}$ \\
\hline \multirow[t]{2}{*}{ Age } & $-0.0227 * * *$ & $0.00407 * * *$ & $-0.00220^{* * *}$ & $-0.00187 * * *$ \\
\hline & $(0.00171)$ & $(0.000305)$ & $(0.000167)$ & $(0.000146)$ \\
\hline \multirow[t]{2}{*}{ Victim of child marriage } & $-0.208 * * *$ & $0.0373 * * *$ & $-0.0201 * * *$ & $-0.0171 * * *$ \\
\hline & $(0.0323)$ & $(0.00578)$ & $(0.00314)$ & $(0.00268)$ \\
\hline \multicolumn{5}{|l|}{ Partners Education } \\
\hline \multicolumn{5}{|l|}{ Base $=$ no education } \\
\hline \multirow[t]{2}{*}{ Primary } & $0.511 * * *$ & $-0.113 * * *$ & $0.0723 * * *$ & $0.0411 * * *$ \\
\hline & $(0.0371)$ & $(0.00941)$ & $(0.00604)$ & $(0.00371)$ \\
\hline \multirow[t]{2}{*}{ Secondary or more } & $1.355^{* * *}$ & $-0.380 * * *$ & $0.189 * * *$ & $0.191 * * *$ \\
\hline & $(0.0445)$ & $(0.0159)$ & $(0.00763)$ & $(0.0101)$ \\
\hline \multicolumn{5}{|l|}{ Wealth Index } \\
\hline \multicolumn{5}{|l|}{ Base $=$ Poorest } \\
\hline \multirow[t]{2}{*}{ Poorer } & $0.154 * * *$ & $-0.0232 * * *$ & $0.0154 * * *$ & $0.00785^{* * *}$ \\
\hline & $(0.0592)$ & $(0.00880)$ & $(0.00585)$ & $(0.00297)$ \\
\hline \multirow[t]{2}{*}{ Middle } & $0.254 * * *$ & $-0.0401 * * *$ & $0.0263 * * *$ & $0.0138 * * *$ \\
\hline & $(0.0574)$ & $(0.00881)$ & $(0.00583)$ & $(0.00303)$ \\
\hline \multirow[t]{2}{*}{ Richer } & $0.437 * * *$ & $-0.0753 * * *$ & $0.0483 * * *$ & $0.0270 * * *$ \\
\hline & $(0.0560)$ & $(0.00909)$ & $(0.00605)$ & $(0.00320)$ \\
\hline \multirow[t]{2}{*}{ Richest } & $0.940 * * *$ & $-0.200 * * *$ & $0.119 * * *$ & $0.0814 * * *$ \\
\hline & $(0.0621)$ & $(0.0135)$ & $(0.00862)$ & $(0.00539)$ \\
\hline \multirow[t]{2}{*}{ Married } & $-0.192 * * *$ & $0.0368 * * *$ & $-0.0196 * * *$ & $-0.0172 * * *$ \\
\hline & $(0.0642)$ & $(0.0131)$ & $(0.00690)$ & $(0.00620)$ \\
\hline \multicolumn{5}{|l|}{ Religion } \\
\hline \multicolumn{5}{|l|}{ Base $=$ Muslims } \\
\hline \multirow[t]{2}{*}{ Christians } & $0.366 * * *$ & $-0.0719 * * *$ & $0.0391 * * *$ & $0.0329 * * *$ \\
\hline & $(0.0314)$ & $(0.00650)$ & $(0.00358)$ & $(0.00304)$ \\
\hline \multirow[t]{2}{*}{ Animists and others } & $-0.197 * * *$ & $0.0312 * * *$ & $-0.0178 * * *$ & $-0.0135 * * *$ \\
\hline & $(0.0645)$ & $(0.00964)$ & $(0.00558)$ & $(0.00407)$ \\
\hline \multicolumn{5}{|l|}{ Ethnicity } \\
\hline \multicolumn{5}{|l|}{ Base $=$ Mossi } \\
\hline \multirow[t]{2}{*}{ Peulh } & $-0.210 * * *$ & $0.0343 * * *$ & $-0.0190 * * *$ & $-0.0153 * * *$ \\
\hline & $(0.0657)$ & $(0.0100)$ & $(0.00565)$ & $(0.00441)$ \\
\hline \multirow[t]{2}{*}{ Gourmatche } & -0.0120 & 0.00212 & -0.00116 & -0.000957 \\
\hline & $(0.0655)$ & $(0.0115)$ & $(0.00629)$ & $(0.00518)$ \\
\hline \multirow[t]{2}{*}{ Others } & $0.133 * * *$ & $-0.0246 * * *$ & $0.0133 * * *$ & $0.0113^{* * *}$ \\
\hline & $(0.0307)$ & $(0.00576)$ & $(0.00313)$ & $(0.00265)$ \\
\hline \multirow[t]{2}{*}{ Rural } & $-0.380 * * *$ & $0.0681 * * *$ & $-0.0368 * * *$ & $-0.0313 * * *$ \\
\hline & $(0.0374)$ & $(0.00666)$ & $(0.00363)$ & $(0.00314)$ \\
\hline Constant cut 1 & 0.170 & & & \\
\hline & $(0.122)$ & & & \\
\hline Constant cut 2 & $1.109 * * *$ & & & \\
\hline & $(0.123)$ & & & \\
\hline Observations & 13,883 & 13,883 & 13,883 & 13,883 \\
\hline
\end{tabular}

Standard errors in parentheses.

$* * *: \mathrm{p}<0.01, * *: \mathrm{p}<0.05, *: \mathrm{p}<0.1$. 

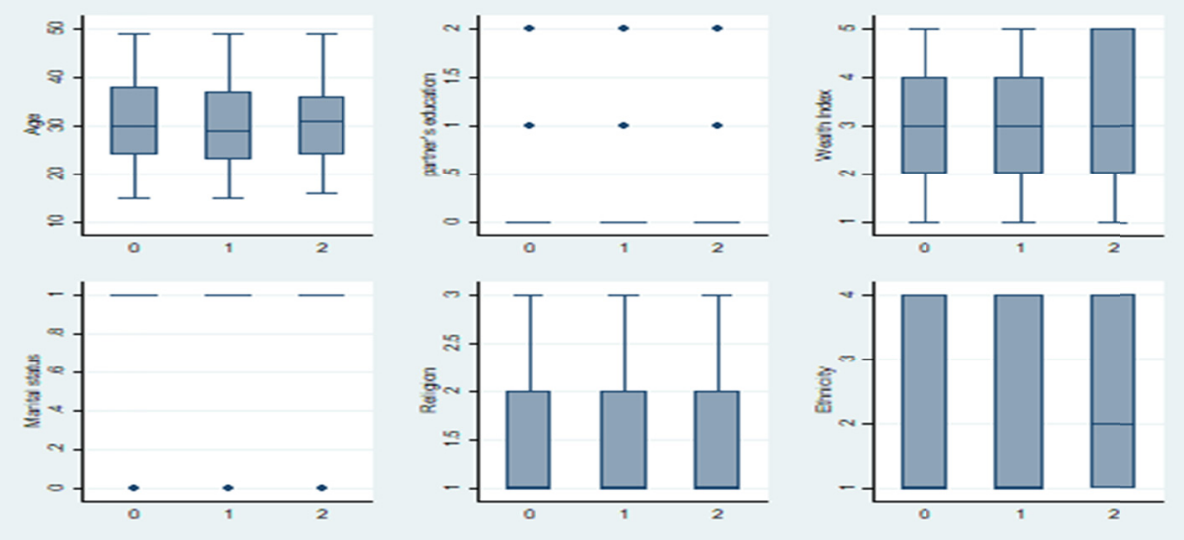

$0=$ no education, $1=$ primary, $2=$ secondary and more

Figure 2. Boxplot by the level of education after weighting

\subsection{Estimating the Effect of Education on Fertility Decisions Using the PSW}

Table 4 presents the results of the impact of education on the number of children and the average age at first birth using the weighted sample. For each outcome variable, we report the coefficient of regression and incidence-rate ratios (IRR). Robust standard errors are presented in parentheses. The results in Table 4 suggest that women with primary education have 0.950 more children than uneducated women in Burkina Faso. This effect is significant at any threshold. Table 4 also suggests that having a secondary or higher level of education delays women's first birth by roughly one year. Interestingly, the results suggest that the partner education also reduces the number of children. In fact, women whose partners have at least a primary school education tend to have 0.96 children than those whose partners have no education at all. This effect is close to the effect of female education suggesting that the partner's education matter as well as the woman education. This result is explained by social norms in Burkina Faso where the husband is considered as the head of the household and can also decide about the number of children. We also observed that women from richer families tend to have fewer children. This result is particularly important in the fight against poverty. Family size is indeed both a cause and a consequence of poverty. The policies which aim at reducing women fertility should also target family poverty. Our results also suggest that women who have been victims of child marriage have 1.12 more children than their counterparts who have gotten married at a mature age (after 18). Finally, the results suggest that working females have fewer children than women who do not participate in the labour market. These results reveal the trade-off between childcare and employment for women in Burkina Faso.

Table 4. Estimates of the impact of education on fertility with weight score

\begin{tabular}{lcccc}
\hline VARIABLES & $\begin{array}{c}(1) \\
\text { Number of children }\end{array}$ & $\begin{array}{c}(2) \\
\text { IRR }\end{array}$ & Age at first birth & $\begin{array}{c}(4) \\
\text { IRR }\end{array}$ \\
\hline Woman's Education & & & & \\
Base= (No education) & & & & \\
Primary & $-0.0404^{* *}$ & $0.960^{* *}$ & $(0.00514$ & $(0.005$ \\
& $(0.0162)$ & $(0.0156)$ & $(0.00378)$ & $1.028^{* * *}$ \\
Secondary or more & -0.0616 & 0.940 & $0.0274^{* * *}$ & $(0.00790)$ \\
& $(0.0467)$ & $(0.0439)$ & $(0.00769)$ & \\
Partner's Education & & & & 0.999 \\
Base= (No education) & & & -0.000922 & $(0.00308)$ \\
Primary & $-0.0352^{* * *}$ & $0.965^{* * *}$ & $(0.00308)$ & $1.017^{* * *}$ \\
Secondary or more & $(0.0127)$ & $(0.0122)$ & $0.0172^{* * *}$ & $(0.00527)$ \\
Wealth Index & $-0.195^{* * *}$ & $0.823^{* * *}$ & $(0.00518)$ & \\
Base= (Poorest) & $(0.0226)$ & $(0.0186)$ & & \\
\hline
\end{tabular}




\begin{tabular}{|c|c|c|c|c|}
\hline \multirow[t]{2}{*}{ Poorer } & -0.0202 & 0.980 & -0.00462 & 0.995 \\
\hline & $(0.0149)$ & $(0.0146)$ & $(0.00364)$ & $(0.00362)$ \\
\hline \multirow[t]{2}{*}{ Middle } & $-0.0420 * * *$ & $0.959 * * *$ & -0.00555 & 0.994 \\
\hline & $(0.0147)$ & $(0.0141)$ & $(0.00365)$ & $(0.00363)$ \\
\hline \multirow[t]{2}{*}{ Richer } & $-0.0670 * * *$ & $0.935 * * *$ & -0.00141 & 0.999 \\
\hline & $(0.0158)$ & $(0.0148)$ & $(0.00392)$ & $(0.00392)$ \\
\hline \multirow[t]{2}{*}{ Richest } & $-0.162 * * *$ & $0.851 * * *$ & -0.000533 & 0.999 \\
\hline & $(0.0203)$ & $(0.0173)$ & $(0.00454)$ & $(0.00454)$ \\
\hline \multirow[t]{2}{*}{ Married } & $0.0923 * *$ & $1.097 * *$ & -0.00849 & 0.992 \\
\hline & $(0.0399)$ & $(0.0438)$ & $(0.00635)$ & $(0.00629)$ \\
\hline \multirow[t]{2}{*}{ Victim of child marriage } & $0.118 * * *$ & $1.125 * * *$ & $-0.108 * * *$ & $0.898 * * *$ \\
\hline & $(0.00964)$ & $(0.0108)$ & $(0.00251)$ & $(0.00225)$ \\
\hline \multicolumn{5}{|l|}{ Age (Base=15-19) } \\
\hline \multirow[t]{2}{*}{$20-24$} & $1.015 * * *$ & $2.760 * * *$ & -0.00348 & 0.997 \\
\hline & $(0.0376)$ & $(0.104)$ & $(0.00367)$ & $(0.00366)$ \\
\hline \multirow[t]{2}{*}{$25-29$} & $1.607 * * *$ & $4.989 * * *$ & $0.0182 * * *$ & $1.018^{* * *}$ \\
\hline & $(0.0362)$ & $(0.180)$ & $(0.00387)$ & $(0.00395)$ \\
\hline \multirow[t]{2}{*}{$30-34$} & $1.981 * * *$ & $7.247 * * *$ & $0.0252 * * *$ & $1.026^{* * *}$ \\
\hline & $(0.0360)$ & $(0.261)$ & $(0.00421)$ & $(0.00432)$ \\
\hline \multirow[t]{2}{*}{$35-39$} & $2.232 * * *$ & $9.322 * * *$ & $0.0363^{* * *}$ & $1.037 * * *$ \\
\hline & $(0.0365)$ & $(0.340)$ & $(0.00464)$ & $(0.00482)$ \\
\hline \multirow[t]{2}{*}{$40-44$} & $2.384 * * *$ & $10.85 * * *$ & $0.0427 * * *$ & $1.044 * * *$ \\
\hline & $(0.0367)$ & $(0.398)$ & $(0.00468)$ & $(0.00489)$ \\
\hline \multirow[t]{2}{*}{$45-49$} & $2.488 * * *$ & $12.03 * * *$ & $0.0651^{* * *}$ & $1.067 * * *$ \\
\hline & $(0.0381)$ & $(0.458)$ & $(0.00559)$ & $(0.00596)$ \\
\hline \multirow[t]{2}{*}{ Working } & $-0.0225^{*}$ & $0.978^{*}$ & 0.00514 & 1.005 \\
\hline & $(0.0116)$ & $(0.0114)$ & $(0.00318)$ & $(0.00320)$ \\
\hline \multicolumn{5}{|l|}{ Religion } \\
\hline \multicolumn{5}{|l|}{ Base $=$ Muslims } \\
\hline \multirow[t]{2}{*}{ Christians } & -0.0154 & 0.985 & 0.00361 & 1.004 \\
\hline & $(0.0122)$ & $(0.0120)$ & $(0.00273)$ & $(0.00274)$ \\
\hline \multirow[t]{2}{*}{ Animists and others } & -0.00324 & 0.997 & -0.00280 & 0.997 \\
\hline & $(0.0241)$ & $(0.0240)$ & $(0.00395)$ & $(0.00394)$ \\
\hline \multicolumn{5}{|l|}{ Ethnicity } \\
\hline \multicolumn{5}{|l|}{ Base $=$ mossis } \\
\hline \multirow[t]{2}{*}{ Peulh } & $-0.0491 * * *$ & $0.952 * * *$ & $0.0113^{*}$ & $1.011 *$ \\
\hline & $(0.0174)$ & $(0.0166)$ & $(0.00612)$ & $(0.00619)$ \\
\hline Gourmatche & $0.0426^{* *}$ & $1.044 * *$ & 0.00102 & 1.001 \\
\hline & $(0.0204)$ & $(0.0213)$ & $(0.00675)$ & $(0.00676)$ \\
\hline Others & $-0.0345 * * *$ & $0.966^{* * *}$ & 0.000157 & 1.000 \\
\hline & $(0.0118)$ & $(0.0114)$ & $(0.00307)$ & $(0.00307)$ \\
\hline Rural & $0.0692 * * *$ & $1.072 * * *$ & $0.00584^{*}$ & $1.006^{*}$ \\
\hline & $(0.0113)$ & $(0.0122)$ & $(0.00307)$ & $(0.00309)$ \\
\hline Constant & $-0.709 * * *$ & $0.492 * * *$ & $3.019 * * *$ & $20.47 * * *$ \\
\hline & $(0.0627)$ & $(0.0309)$ & $(0.0106)$ & $(0.218)$ \\
\hline Pearson goodness-of-fit & 6447.101 & 6447.101 & 2383.375 & 2383.375 \\
\hline P-value & 1.000 & 1.000 & 1.000 & 1.000 \\
\hline T-test $(\mathrm{T} 1=\mathrm{T} 2)$ & 3.30 & 3.30 & 5.53 & 5.53 \\
\hline P-value & 0.069 & 0.069 & 0.018 & 0.018 \\
\hline F-test $(\mathrm{T} 1=\mathrm{T} 2=0)$ & 26.11 & & 11.64 & 11.64 \\
\hline P-value & 0.000 & 0.000 & 0.003 & 0.003 \\
\hline Observations & 13,792 & 13,792 & 12,896 & 12,896 \\
\hline
\end{tabular}

Robust standard errors in parentheses.

$* * *: \mathrm{p}<0.01, * *: \mathrm{p}<0.05, *$ : $\mathrm{p}<0.1$. 
Table 5 presents the estimated average number of children and the age at first birth by education levels. The average number of children is 4.058 for women with no education and 3.854 and 3.651 for women with primary and secondary education respectively. Educated women, therefore, tend to have fewer children. In addition, Table 5 shows that educated women tend to enter in motherhood later than uneducated women. In fact uneducated women have at average their first birth at 18.97-year-old while women with at least a primary and a secondary education have their first child at 19.07 and 19.46 years old respectively. These results are consistent with Zanin et al. (2015) and Bbaale and Mpuga (2011) who find that education reduce women's fertility in Africa.

Table 5. Average fertility outcome by the level of education

\begin{tabular}{lcc}
\hline VARIABLES & Average number of children & Average age at first birth \\
\hline Uneducated & $4.058^{* * *}$ & $18.97^{* * *}$ \\
& $(0.0137)$ & $(0.0201)$ \\
Primary education & $3.854^{* * *}$ & $19.07^{* * *}$ \\
& $(0.0560)$ & $(0.0708)$ \\
Secondary and higher & $3.651^{* * *}$ & $19.46^{* * *}$ \\
& $(0.0966)$ & $(0.153)$ \\
Observations & 13,792 & 12,896 \\
\hline
\end{tabular}

Standard errors in parentheses.

$* * *: \mathrm{p}<0.01, * *: \mathrm{p}<0.05, *: \mathrm{p}<0.1$.

\section{Conclusion and Discussion}

During this last decade, the role of education in women's family planning behaviour and fertility preference has been a great interest in developing countries(Khan, Mishra, Arnold, \& Abderrahim, 2007; Cohen, Kravdal, \& Keilman, 2011; Pradhan \& Canning, 2013; Rodríguez-Vignoli \& Cavenaghi, 2014; Testa, 2014). However, due to education endogeneity, empirical studies struggle to identify and quantify the impact of education on fertility. Using data from the 2014 Demographic and Health Survey, this paper examines the causal effects of education on fertility outcomes in Burkina Faso. The preliminary descriptive analysis suggests a difference in terms of access to education. Using the propensity score weighting approach, we follow Imbens (2000) to create an appropriate counterfactual group that is used to estimate the average effect of education levels on women's fertility.

Our results suggest that education reduces the number of children per woman and delays women's first birth. In addition, we find that the partner's education is negatively related to the number of children and delay the first birth. In fact, education increases women's empowerment and understanding of the benefit of contraception use leading to a reduction of the fertility. Hence, promoting girls' schooling is an efficient policy to reduce women's fertility. Given the evidence that the decline in fertility in developing countries is advocated to create the potential for a demographic dividend and a window of opportunity for economic growth (Karra et al., 2017), policies to reduce the demographic growth in Burkina Faso should also target women's education. Moreover, the results suggest that family wealth index also negatively affects women's fertility. If the literature points on fertility as a cause of poverty in developing countries (Birdsall \& Griffin, 1988), our results then suggest that fertility is also a consequence of poverty. This result is particularly important in the fight against poverty since its reinforce the widespread idea that fertility is positively correlated with poverty (Birdsall \& Griffin, 1988). We also find that women who have been victims of child marriage have more children than their counterparts who have gotten married after the age of 18. As a substantial barrier to social and economic development in developing countries, child marriage is significantly associated with women's increased risk for no contraceptive use (Raj et al., 2009). In such a situation, child marriage reduces women fertility control behaviours leading to a higher number of children and early motherhood. Policies should also fight against child marriage in Burkina Faso in order to reduce the demographic growth. Finally, we also find that working females have fewer children than women who do not participate in the labour market. The inverse relationship between women's work and fertility has been highlighted in the literature as the result of a conflict between working and caring for children (Mason \& Palan, 1981). In fact, women permanently struggle between childcare and labour force participation. Policies that promote women's participation in the labour force may help to reduce fertility rates. To summary our results suggest that education reduce women's fertility in Burkina Faso. In addition other factors like the partner's education, the family wealth, child marriage and employment status also affect women's fertility. 
However, due to missing data, this study does not focus on the quality of education. An interesting direction for future research will be to analyze the effect of sexual education on women's fertility in developing countries. In addition, the effect of fertility on economic development is an empirical puzzle calling for more evidence.

\section{References}

Aslam, M. (2013). Empowering Women: Education and the Pathways of Change. Background paper prepared for the Education for All Global Monitoring. Retrieved from http://unesdoc.unesco.org/images/0022/002259/225925e.pdf

Bbaale, E., \& Mpuga, P. (2011). Female education, contraceptive use, and fertility: evidence from Uganda. Consilience, 6, 20-47. Retrieved from https://consiliencejournal.org/wp-content/uploads/sites/25/2016/09/ 234-500-1-PB.pdf

Bhat, R. A. (2015). Role of Education in the Empowerment of Women in India.

Birdsall, N. M., \& Griffin, C. C. (1988). Fertility and poverty in developing countries. Journal of Policy Modelling, 10(1), 29-55. https://doi.org/10.1016/0161-8938(88)90034-8

Black, S. E., Devereux, P. J., \& Salvanes, K. G. (2008). Staying in the classroom and out of the maternity ward? The effect of compulsory schooling laws on teenage births. The Economic Journal, 118(530), 1025-1054. Retrieved from https://onlinelibrary.wiley.com/doi/abs/10.1111/j.1468-0297.2008.02159.x

Bongaarts, J. (2016). Development: Slow down population growth. Nature News, 530(7591), 409. Retrieved from https://www.nature.com/news/development-slow-down-population-growth-1.19415

Bongaarts, J., \& Casterline, J. (2013). Fertility transition: Is sub-Saharan Africa different? PoPulation and develoPment review, 38(s1), 153-168. Retrieved from https://onlinelibrary.wiley.com/doi/pdf/10.1111/j.1728 $-4457.2013 .00557 . \mathrm{x}$

Caliendo, M., \& Kopeinig, S. (2008). Some practical guidance for the implementation of propensity score $\begin{array}{lllll}\text { matching. Journal of economic } & \text { surveys, } & 22(1), & 31-72 .\end{array}$ doi:https://onlinelibrary.wiley.com/doi/abs/10.1111/j.1467-6419.2007.00527.x

Casterline, J. B., \& El-Zeini, L. O. (2014). Unmet Need and Fertility Decline: A Comparative Perspective on Prospects in Sub-Saharan Africa. Studies in family planning, 45(2), 227-245. Retrieved from https://onlinelibrary.wiley.com/doi/abs/10.1111/j.1728-4465.2014.00386.x

Chicoine, L. (2012). Education and fertility: Evidence from a policy change in Kenya. Retrieved from https://papers.ssrn.com/sol3/papers.cfm?abstract_id $=2157920$

Cohen, J. E., Kravdal, Ø., \& Keilman, N. (2011). Childbearing impeded education more than education impeded childbearing among Norwegian women. Proceedings of the National Academy of Sciences, 108(29), 11830-11835. Retrieved from http://www.pnas.org/content/108/29/11830.short

Currie, J., \& Moretti, E. (2003). Mother's education and the intergenerational transmission of human capital: Evidence from college openings. The Quarterly Journal of Economics, 118(4), 1495-1532. Retrieved from https://academic.oup.com/qje/article/118/4/1495/1925120

Doliger, C. (2004). Le rôle de l'éducation dans la baisse de la fécondité d'après-guerre. Lameta working parper. Retrieved from http://www.lameta.univ-montp1.fr/Documents/DR2004-11.pdf

Ferré, C. (2009). Age at first child: Does education delay fertility timing? The case of Kenya. Retrieved from https://papers.ssrn.com/sol3/papers.cfm?abstract_id $=1344718$

Garenne, M., \& Ferdi, S. F. (2016). La pression de la population dans les Pays Sahéliens Francophones: Analyse des estimations et projections de population. Development, 168. Retrieved from $\mathrm{http} / /$ horizon.documentation.ird.fr/exl-doc/pleins_textes/divers16-10/010067358.pdf

Grossman, M. (1972). On the concept of health capital and the demand for health. Journal of Political Economy, 80(2), 223-255. Retrieved from https://www.journals.uchicago.edu/doi/abs/10.1086/259880?journalCode= jpe

Imbens, G. W. (2000). The role of the propensity score in estimating dose-response functions. Biometrika, 87(3), 706-710. Retrieved from https://academic.oup.com/biomet/article/87/3/706/293734

Karra, M., Canning, D., \& Wilde, J. (2017). The effect of fertility decline on economic growth in Africa: A macrosimulation model. Population and Development Review, 43, 237-263. Retrieved from https://onlinelibrary.wiley.com/doi/abs/10.1111/padr.12009 
Khan, S., Mishra, V., Arnold, F., \& Abderrahim, N. (2007). Contraceptive trends in developing countries. Retrieved from https://www.popline.org/node/199753

Larsson, C., \& Stanfors, M. (2014). Women's education, empowerment, and contraceptive use in sub-Saharan Africa: findings from recent demographic and health surveys. Etude de la Population Africaine, 28(2), 1022. Retrieved from https://search.proquest.com/openview/3823d12fe7409e20efe394f2b6c5245e/1?pq-origsite= gscholar\&cbl=2031869

Leon, A. (2004). The effect of education on fertility: evidence from compulsory schooling laws (Unpublished paper). University of Pittsburgh. Retrieved from https://core.ac.uk/download/pdf/6388153.pdf

Lompo, M. L., Bago, J.-L., \& Souratié, W. M. (2018). Estimating the Impact of School Education on Contraception Use among Adolescents Aged 15-19 in Burkina Faso and Nigeria Using a Heckman Correction Model. Journal of Education and Learning, 7(5), 31. Retrieved from http://www.ccsenet.org/journal/index.php/jel/article/view/75580

Mason, K. O., \& Palan, V. T. (1981). Female employment and fertility in Peninsular Malaysia: The maternal role incompatibility hypothesis reconsidered. Demography, 18(4), 549-575. https://doi.org/10.2307/2060947

MENA. (2014). Annuaire statistique de l'éducation nationale 2013/2014. Direction générale des études et des statistiques sectorielles, Burkina Faso.

Pradhan, E., \& Canning, D. (2013). The Effect of Edcuational Reform in Ethiopia on Girls Schooling and Fertility. Manuscrit nonpublié à ce jour, Harvard School of Public Health, Department of Global Health and Population, Cambridge, MA.

Raj, A., Saggurti, N., Balaiah, D., \& Silverman, J. G. (2009). Prevalence of child marriage and its effect on fertility and fertility-control outcomes of young women in India: a cross-sectional, observational study. The Lancet, 373(9678), 1883-1889. https://doi.org/10.1016/S0140-6736(09)60246-4

Rodríguez-Vignoli, J., \& Cavenaghi, S. (2014). Adolescent and youth fertility and social inequality in Latin America and the Caribbean: what role has education played? Genus, 70(1). Retrieved from https://www.jstor.org/stable/genus.70.1.1?seq=1\#page_scan_tab_contents

Rosenbaum, P. R. (1987). The role of a second control group in an observational study. Statistical Science, 2(3), 292-306. Retrieved from https://projecteuclid.org/euclid.ss/1177013232

Testa, M. R. (2014). On the positive correlation between education and fertility intentions in Europe: Individual-and country-level evidence. Advances in life course research, 21, 28-42. Retrieved from https://www.sciencedirect.com/science/article/pii/S1040260814000069

UN. (2016). Global AIDS up date. Retrieved from http://www.who.int/hiv/pub/arv/global-AIDS-update-2016_en. pdf

Zanin, L., Radice, R., \& Marra, G. (2015). Modelling the impact of women's education on fertility in Malawi. Journal of Population Economics, 28(1), 89-111. Retrieved from https://link.springer.com/article/10.1007/ s00148-013-0502-8

\section{Note}

Note 1. Ministry of National Education and Literacy of Burkina Faso.

\section{Copyrights}

Copyright for this article is retained by the author(s), with first publication rights granted to the journal.

This is an open-access article distributed under the terms and conditions of the Creative Commons Attribution license (http://creativecommons.org/licenses/by/4.0/). 